
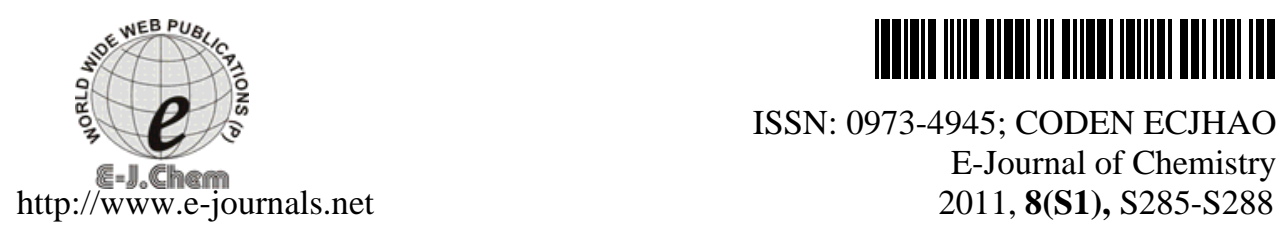

ISSN: 0973-4945; CODEN ECJHAO

E-Journal of Chemistry

2011, 8(S1), S285-S288

\title{
Premilinary Studies on Phytochemical Screening of Ulam and Fruit from Malaysia
}

\author{
LILIWIRIANIS N*, NOR LAILATUL WAHIDAH MUSA, \\ WAN ZURAIDA WAN MOHD ZAIN, \\ JAMALUDDIN KASSIM and SYAIKH ABDUL KARIM \\ Biology Department, Faculty of Applied Sciences, Universiti \\ Teknologi MARA, 26400 Jengka, Pahang, Malaysia \\ liliwirianis@pahang.uitm.edu.my
}

Received 11 August 2011; Accepted 1 November 2011

\begin{abstract}
Alkaloids, saponins, steroid, terpenoid, flavonoids, phenolic distribution in 14 Malaysian favourite ulam and fruit belonging to different families were assessed and compared. The plants investigated were parkia speciosa (petai), solanum torvum (terung pipit), pithecellobium bubalinum (kerdas), moringa oleifera (kacang kelor), dryobalanops oblongifolia (keladan), cosmos caudatus (ulam raja), mentha arvensis (pudina), ocimum sp. (selasih), cymbopogon nardus (serai wangi), eugenia polyantha (serai kayu), Barringtonia scortechinii, (Putat), musa sp. (pisang), talinum paniculatum (akar som) and phyllanthus acidus (cermai). Moringa oleifera leaf and dryobalanops oblongifolia fruit were found contain positive reactions of alkaloids. All the samples studied also show high content of saponin except in bark and seed of parkia speciosa and stem of phyllanthus acidus. Meanwhile, results of the phytochemical screening on saponins, steroids, terpenoids, phenolic and flavonoids showed that cosmos caudatus, ocimum sp., mentha arvensis, barringtonia scortechinii and moringa oleifera were the active compounds present in the leaves of the plant.
\end{abstract}

Keywords: Ulam, Fruit, Phytochemical studies, Alkaloids

\section{Introduction}

Most of Malay people eat a lot of vegetables and they usually eat the vegetable fresh (ulam). They believe that these ulam are beneficial against many diseases and had positive effects. The medicinal value of all the plants lies in some chemical substances. The most important of these bioactive constituents of plants are alkaloids, tannins, flavonoids and phenolic compounds ${ }^{1}$. Plant phenolics are commonly found in both edible and non-edible plants, and have been reported to have multiple biological effects, including antioxidant activity. Besides that, epidemiological studies have shown that there is a positive association 
between intake of vegetables and fruits and reduced cardiovascular diseases ${ }^{2}$ and certain cancers ${ }^{3}$. Along with other antioxidant components, polyphenols (e.g. flavonoids) present in fruits and vegetables have been reported to be potential sources in lowering cardiovascular diseases ${ }^{4}$.

\section{Experimental}

The herbs specimens were bought from Jengka, Pahang market and Jengka area. These specimens were then sent to the botanist for confirmatory identification.

\section{Phytochemical screening}

\section{Alkaloid}

The method of alkaloid testing was carried out according to the procedure of culvenor and Fitzgerald $^{5}$. The presence of most alkaloids in the aqueos phase can be detected by the formation of a precipitate on addition of Mayer reagent $\left(\mathrm{K}_{2} \mathrm{HgI}_{4}\right)$. The semi-quantitative results of the method have been rated from $1+$ for faint turbidity to $4+$ for heave curdy precipitate.

\section{Saponin}

For saponin testing, the method used was the buble testing. If the bubles remains 30 minutes to one hour, it was rated as $1+$, one to two hours: $2+$ and two to three hours, $3+$, and more than three ${ }^{6}$ hours, $4+$.

\section{Phenolic}

Screening for phenolic was carried out by using chloroform extraction; the crude sprayed by $\mathrm{FeCl}_{3}$ will give the blue dot showing the existence of the phenolic.

\section{Terpenoid}

Liquid- solid extraction was used for terpenoid determination. The samples were extracted using the methanol as solvent, then followed by vacuum filtration, and sprayed by the dyeing reagent. The terpenoid existence was shown by the greyish colour on the TLC plate ${ }^{7}$.

\section{Results and Discussion}

The phytochemical screening characters of ulam and fruit investigated are summmarised in Table 1. Alkaloid, terpenoid, saponin and phenolic were present in all the plants studied but in the different part of the species.

Table 1. Phytochemical substances of ulam and fruit investigated

\begin{tabular}{ccccccc}
\hline Samples & Alkaloid & Saponin & Steroid & Phenolic & Flavonoid & Terpenoid \\
\hline \multirow{2}{*}{ T. paniculatum } & $3+(\mathrm{St})$, & $2+(\mathrm{St})$, & $+(\mathrm{St})$, & $+(\mathrm{St}),+$ & $+(\mathrm{St})$, & $+(\mathrm{St})$, \\
Musa sp. & $+(\mathrm{Lf})$ & $2+(\mathrm{Lf})$ & $+(\mathrm{Lf})$ & $(\mathrm{Lf})$ & $-(\mathrm{Lf})$ & $+(\mathrm{Lf})$ \\
C. caudatus & $3+(\mathrm{Fl})$ & $3+(\mathrm{Fl})$ & $-(\mathrm{Fl})$ & $-(\mathrm{Fl})$ & $+(\mathrm{Fl})$ & $-(\mathrm{Fl})$ \\
& $3+(\mathrm{St})$, & $4+(\mathrm{St})$, & $+(\mathrm{St})$, & $-(\mathrm{St})$, & $+(\mathrm{St})$, & $-(\mathrm{St})$, \\
\multirow{4}{*}{ M. arvensis } & $3+(\mathrm{Lf})$ & $4+(\mathrm{Lf})$ & $+(\mathrm{Lf})$ & $+(\mathrm{Lf})$ & $+(\mathrm{Lf})$ & $+(\mathrm{Lf})$ \\
& $2+(\mathrm{St})$, & $3+(\mathrm{St})$, & $+(\mathrm{St})$, & $+(\mathrm{St})$, & $+(\mathrm{St})$, & $+(\mathrm{St})$, \\
\multirow{2}{*}{ Ocimum $\mathrm{sp}}$. & $2+(\mathrm{Lf})$ & $3+(\mathrm{Lf})$ & $+(\mathrm{Lf})$ & $+(\mathrm{Lf})$ & $+(\mathrm{Lf})$ & $+(\mathrm{Lf})$ \\
& $1+(\mathrm{St})$, & $4+(\mathrm{St})$, & $+(\mathrm{St})$, & $-(\mathrm{St})$, & $+(\mathrm{St})$, & $+(\mathrm{St})$, \\
E. polyantha & $1+(\mathrm{Lf})$ & $4+(\mathrm{Lf})$ & $+(\mathrm{Lf})$ & $+(\mathrm{Lf})$ & $+(\mathrm{Lf})$ & $+(\mathrm{Lf})$ \\
& $2+(\mathrm{St})$, & $4+(\mathrm{St})$, & $+(\mathrm{St})$, & $+(\mathrm{St})$, & $+(\mathrm{St})$, & $-(\mathrm{St})$, \\
& $2+(\mathrm{Lf})$ & $4+(\mathrm{Lf})$ & $+(\mathrm{Lf})$ & $+(\mathrm{Lf})$ & $+(\mathrm{Lf})$ & $-(\mathrm{Lf})$ \\
\hline
\end{tabular}




\begin{tabular}{|c|c|c|c|c|c|c|}
\hline C. nardus & $\begin{array}{l}2+(\mathrm{St}), \\
2+(\mathrm{Lf})\end{array}$ & $\begin{array}{l}2+(\mathrm{St}), \\
2+(\mathrm{Lf})\end{array}$ & $\begin{array}{l}\text { - (St), } \\
\text { - (Lf) }\end{array}$ & $\begin{array}{c}-(\mathrm{St}),+ \\
\text { (Lf) }\end{array}$ & $\begin{array}{c}+(\mathrm{St}),+ \\
\text { (Lf) }\end{array}$ & $\begin{array}{c}-(\mathrm{St}),+ \\
\text { (Lf) }\end{array}$ \\
\hline $\begin{array}{c}\text { B. } \\
\text { scortechinii }\end{array}$ & $\begin{array}{l}2+(\mathrm{St}) \\
2+(\mathrm{Lf})\end{array}$ & $\begin{array}{l}1+(\mathrm{St}), \\
1+(\mathrm{Lf})\end{array}$ & $\begin{array}{l}+(\mathrm{St}), \\
+(\mathrm{Lf})\end{array}$ & $\begin{array}{c}+(\mathrm{St}),+ \\
\quad(\mathrm{Lf})\end{array}$ & $\begin{array}{c}+(\mathrm{St}),+ \\
\quad(\mathrm{Lf})\end{array}$ & $\begin{array}{c}+(\mathrm{St}),+ \\
\quad(\mathrm{Lf})\end{array}$ \\
\hline P. speciosa & $\begin{array}{l}-(\mathrm{Lf}) \\
2+(\mathrm{Sd}), \\
1+(\mathrm{Br}), \\
1+(\mathrm{Sc})\end{array}$ & $\begin{array}{l}4+(\mathrm{Lf}), \\
-(\mathrm{Sd}), \\
-(\mathrm{Br}), \\
4+(\mathrm{Sc})\end{array}$ & $\begin{array}{c}+(\mathrm{Lf}) \\
-(\mathrm{Sd}), \\
-(\mathrm{Br}),-(\mathrm{Sc})\end{array}$ & $\begin{array}{c}+(\mathrm{Lf}), \\
-(\mathrm{Sd}),+ \\
(\mathrm{Br}),-(\mathrm{Sc})\end{array}$ & $\begin{array}{l}+(\mathrm{Lf}),+ \\
(\mathrm{Sd})-(\mathrm{Br}) \\
\quad+(\mathrm{Sc})\end{array}$ & $\begin{array}{c}-(\mathrm{Lf}),+(\mathrm{Sd}) \\
-(\mathrm{Br}),- \\
\text { (Sc) }\end{array}$ \\
\hline S. torvum & $\begin{array}{l}1+(\mathrm{Fr}) \\
1+(\mathrm{Br})\end{array}$ & $\begin{array}{l}2+(\mathrm{Fr}), \\
1+(\mathrm{Br})\end{array}$ & $\begin{array}{l}+(\mathrm{Fr}), \\
+(\mathrm{Br})\end{array}$ & $\begin{array}{l}+(\mathrm{Fr}), \\
+(\mathrm{Br})\end{array}$ & $\begin{array}{c}+(\mathrm{Fr}),- \\
(\mathrm{Br})\end{array}$ & - (Fr), - (Br) \\
\hline P. acidus & $\begin{array}{l}1+(\mathrm{St}) \\
2+(\mathrm{Lf})\end{array}$ & $\begin{array}{l}-(\mathrm{St}) \\
3+(\mathrm{Lf})\end{array}$ & $\begin{array}{l}+(\mathrm{St}), \\
-(\mathrm{Lf})\end{array}$ & $\begin{array}{l}-(\mathrm{St}), \\
+(\mathrm{Lf})\end{array}$ & $\begin{array}{l}+(\mathrm{St}), \\
-(\mathrm{Lf})\end{array}$ & $\begin{array}{l}-(\mathrm{St}), \\
+ \text { (Lf) }\end{array}$ \\
\hline M. oleifera & $4+(\mathrm{Lf})$ & $2+(\mathrm{Lf})$ & $+(\mathrm{Lf})$ & $+(\mathrm{Lf})$ & $+(\mathrm{Lf})$ & $+(\mathrm{Lf})$ \\
\hline D. oblongifolia & $4+(\mathrm{Fr})$ & $4+(\mathrm{Fr})$ & $+(\mathrm{Fr})$ & $+(\mathrm{Fr})$ & - (Fr) & - (Fr) \\
\hline P.bubalinum & $4+(\mathrm{Fr})$ & $4+(\mathrm{Fr})$ & $-(\mathrm{Fr})$ & $-(\mathrm{Fr})$ & $+(\mathrm{Fr})$ & $-(F r)$ \\
\hline
\end{tabular}

${ }^{*}$ Lf(leaves), Br(bark), St(stem),Fr(fruit), Sd(seed), Sc (seed coat), Present of constituents; Steroid; +, present and -, absent, Phenolic; +, present and -, absent, Flavonoid; +, present and -, absent, Terpenoid; +, present and -, absent

Alkaloid was present in all the samples but in the different parts of the plants except on $P$. speciosa leaves. The P.speciosa leaves also shown negative result on terpenoid existence but shown positive result on saponin existence (4+). However, $P$. speciosa seeds reported by Che Yunus et al., ${ }^{8}$ contain terpenoids compounds of $\beta$-sitosterol and squalene. It is interesting to note that the analysis of different plant parts (leaf, seed, bark and seed coat) resulted in various existence of the entire compound studied. P. acidus also show an existence of alkaloid compound and phenolic compound (leaf). Similar result were obtained by Komuraiah et al., ${ }^{9}$ that revealed the presence of high amounts of alkaloids and phenols in the extract of the same genera of the sample studied, P. amarus.

Most positive existence of alkaloid can be found on M. oleifera leaf, D. oblongifolia fruit and Pi. bubalinum fruit with 4+. M. oleifera result are parallel to the earlier studies conducted on root of the species that shown the existence of alkaloid ${ }^{10}$. Besides that, other researcher reported that the leaves of M. oleifera can be good sources of proteins for animal feeds ${ }^{11}$. Siddhuraju and Becker ${ }^{12}$ also reported that $M$. oleifera show an existence of phenolic content, where their study reported on total phenolic content in three different climates.

Phenolic compound existence are negative on stem of $C$. caudatus, Ocimum sp., C. nardus, $P$. acidus, flower of Musa sp., fruit of P.bubalinum, seed and seed coat of $P$. speciosa. This result is contrast to study done by Mustafa et al., ${ }^{13}$, who reported that $C$. caudatus show an existence of phenolic content. The difference in the findings might be due to part of the sample studied. However, this study is parallel to the finding of their study based on the existence of flavonoid compound in C. caudatus. And most of the sample studied gives a positive result on flavonoid compound. Alkaloids ${ }^{14}$ and phenols ${ }^{15}$ have been reported to possess antimicrobial activity.

Study done by Mohd Azizi et al., ${ }^{16}$, reported that other species of Pithecellobium, $P$. jiringan seeds contain terpenoids, flavonoid and alkaloid compounds. This study confirms the result on $P$. bubalinum that show an existence on the entire compound except absence on terpenoid compound on seed/fruit. From the study, fruit and bark of $S$. torvum gave positive reactions of alkaloid, saponin, steroid and phenolic. Previous studied confirm the main constituents in the fruits of $S$. torvum are steroidal alkaloids ${ }^{17}$, tannins and saponins ${ }^{18}$. And the methanolic extract from the fruits of $S$. torvum showed interesting growth inhibiting activity against bacterial species commonly associated with pyogenic infections ${ }^{19}$. 
For saponin test, stem and leaves of $C$. caudatus, Ocimum sp and E. polyantha, leaves and seed coat of P.speciosa and fuit of D. oblongifolia and P. bubalinum extract gave a strong positive reaction in all parts studied (4+), which indicated that the part containing high content of saponin. Absence of saponin content was shown on seed and bark of P.speciosa and stem of P. acidus. Meanwhile study on flavonoid content shown negative results on leaf of T. paniculatum, $P$. acidus and bark of $P$. speciosa, and fruit of $D$. oblongifolia. Based on this study, it also shown that stem of $T$. paniculatum, leaves of $M$. oleifera, stem and leaves of $B$. scortechinii and $M$. arvensis shown positive reaction on alkaloids, saponins, steroid, terpenoid, flavonoids, phenolic content.

\section{Conclusion}

Major of the ulam and fruit studied had the compound that can be introduced antimicrobial and antioxidant sources. Further studies need to be done for better understanding on their clinical actions against many diseases. This study also reconfirms the potential of Malaysian favourite fruit and ulam are potential in usage in the treatment of bacterial diseases besides developing some new drugs. It is important to include these ulam and fruit in health promotion campaigns. In addition, some of these ulam have the potential to be used and processed as food products for local consumption.

\section{References}

1. Hill A F, Economic Botany. A textbook of useful plants and plant products. $2^{\text {nd }}$ Ed., McGraw-Hill Book Company Inc, New York, 1952.

2. Hu F B, Am J Clin Nut., 2003, 78(3), 544S-551S.

3. Riboli E and Norat T, Am J Clin Nut., 2003, 78(3), 559S-569S.

4. Huxley R R and Neil H A W, Eur J Clin Nut., 2003, 57, 904-908.

5. $\quad$ Culvenor C C J and Fitzgerald J S, J Pharm Sci., 1963, 52, 303-306.

6. Said I M, Din L B, Samsudin M W, Zakaria Z, Yusoff N I, Suki U, Manap A and Ibrahim A Z and Latiff A, Malay Nature J., 1990, 43, 260-266.

7. Vogel H, Gonzolez M, Faini F, Razmillic I, Rodriguez J, Martin J S and Urbina F. Ethnopharmacology., 2005, 97, 97-100.

8. Che Yunus, Mohd Azizi and Salman Z and Nik Norulain N A. and Mohd Omar A K, $J$ Chemical Natural Resources Engineering -Sustainable Process for Natural Resources, 2008, 2, 153-163.

9. Komuraiah A, Bolla K, Rao K N, Ragan A, Raju V S and Charya M A S, African J Biotechnol., 2009, 8(19), 4991-4995.

10. Mazumder U K, Gupta M, Chakrabarti S and Pal D, Indian J Exp Biol., 1999, 37(6), 612-614.

11. Makkar M, H P S and Becker K, J Agric Sci., 1997, 128(3), 311-322.

12. Siddhuraju P and Becker K, J Agric Food Chem., 2003, 51, 2144-2155.

13. Mustafa R A, Abdul Hamid A, Mohamed S and Abu Bakar F, J Food Sci., 2010, 75(1), C28-C35.

14. Akinyemi K O, Oladapo O, Chidi E O, Christopher C, Ibe and Fasure K A, BMC Complimentary Alernative Medicine, 2005,. 5(6), 1-7.

15. Houghton P J, Woldemariam T Z, O’Shea S, Mullen J E, Rostron T, Bantvala J E, Walker E, Thyagarajan S P, Soloman and Foo S Y, J Pharm Pharmacol., 1999, 51, 100.

16. Mohd Azizi C Y, Nik Norulaini N A, Zhari I, Wahyu B. S and Mohd Omar A K, International Conference on Natural Resources Engineering \& Technology, 2006. 24-25 ${ }^{\text {th }}$ July 2006; Putrajaya, Malaysia, 2006, 616-625.

17. Yahara S, Yamashita T, Nozawa N and Nohara T, Phytochem., 1996, 43, 1069-1074.

18. Huda-Faujan N, Noriham A, Norrakiah A S and Babji A S, African J Biotechnol., 2009, 8(3), 484-489.

19. Chah K F, Muko K N and Oboegbulem S I, Fitoterapia., 2000, 71, 187-189. 


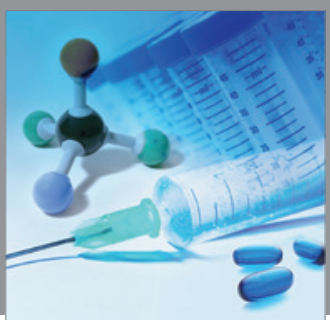

International Journal of

Medicinal Chemistry

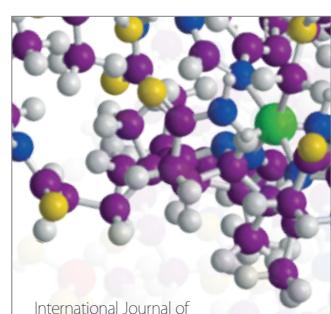

Carbohydrate Chemistry

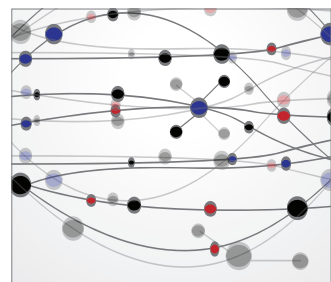

The Scientific World Journal
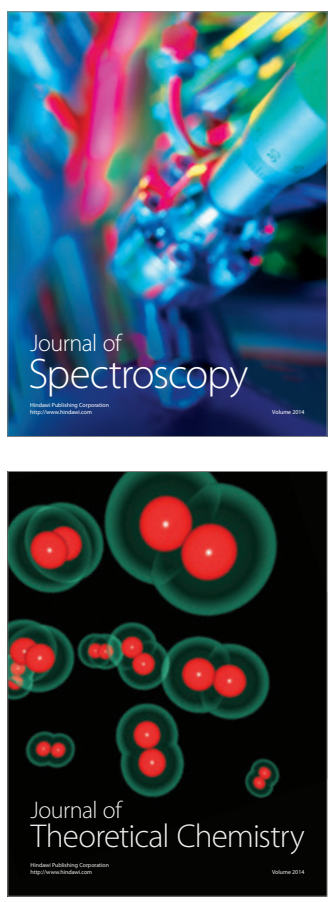
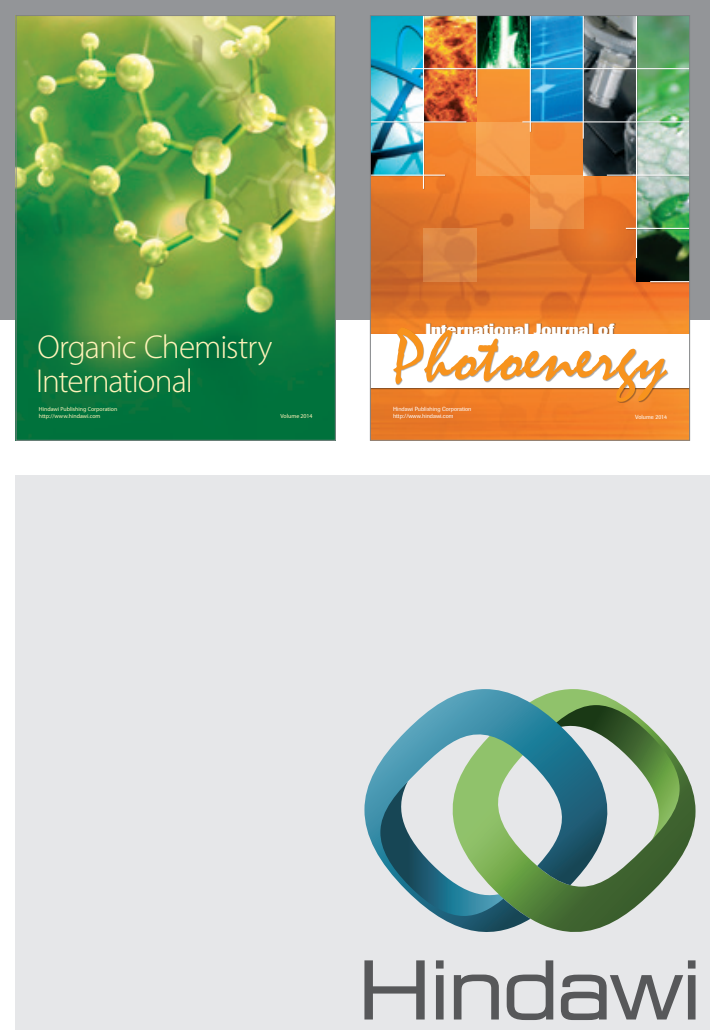

Submit your manuscripts at

http://www.hindawi.com
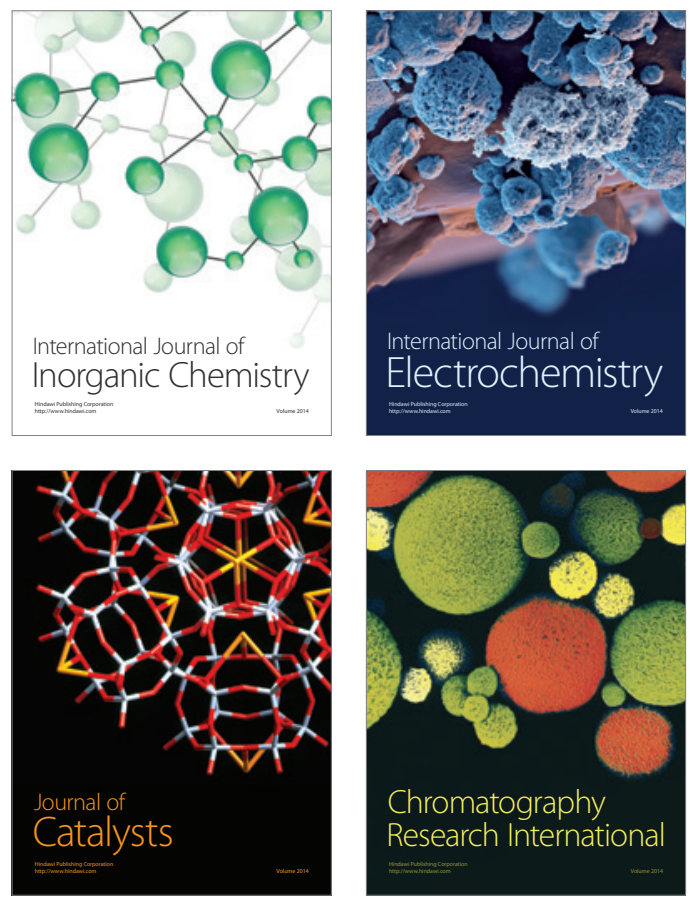
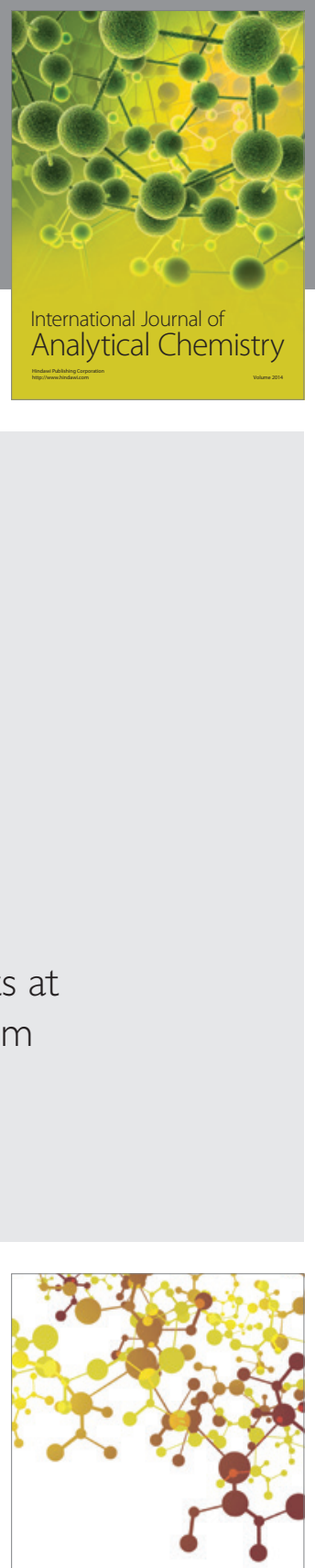

Journal of

Applied Chemistry
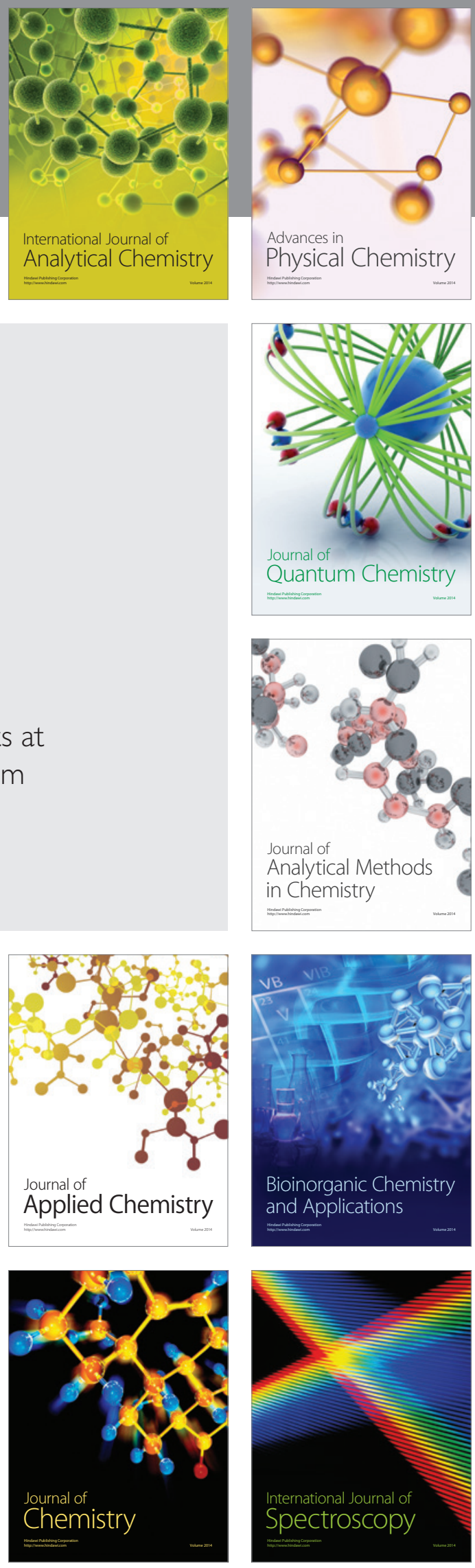